\title{
Immunocytochemistry of GLUT2, uptake of fluorescent desnitroso-streptozotocin analogs and phosphorylation of D-glucose in INS-1E cells
}

\author{
MYRNA VIRREIRA ${ }^{1}$, IULIANA POPESCU ${ }^{2}$, CELINE GILLET $^{3}$, YING ZHANG ${ }^{4}$, YEVGENIY LESHCH ${ }^{5}$, \\ JULIAN THIMM ${ }^{5}$, JOACHIM THIEM ${ }^{5}$, WILLY J. MALAISSE ${ }^{4}$ and ABDULLAH SENER ${ }^{4}$ \\ ${ }^{1}$ Laboratory of Cell and Molecular Physiology; ${ }^{2}$ Laboratory of Histology, Neuroanatomy and Neuropathology; \\ ${ }^{3}$ Laboratory of Biological Chemistry and Nutrition; ${ }^{4}$ Laboratory of Experimental Hormonology, Université Libre de Bruxelles, \\ Brussels B-1070, Belgium; ${ }^{5}$ Department of Chemistry, University of Hamburg, Hamburg D-20146, Germany
}

Received March 27, 2013; Accepted June 20, 2013

DOI: $10.3892 / \mathrm{mmr} .2013 .1559$

\begin{abstract}
The non-invasive imaging of GLUT2-expressing cells remains a challenge. As streptozotocin, and similarly alloxan, may be transported into cells by GLUT2, the major aim of the present study was to assess the possible use of fluorescent desnitroso-streptozotocin analogs for in vitro labeling of GLUT2-expressing cells. INS-1E cells, human embryonic kidney (HEK) cells, rat isolated pancreatic islets, rat hepatic cells, rat exocrine pancreatic cells and tumoral insulinproducing BRIN-BD11 cells were incubated in the presence of two distinct fluorescent desnitroso-streptozotocin analogs, probes A and B. The immunocytochemistry of GLUT2 in INS-1E cells and the phosphorylation of D-glucose by INS-1E cell homogenates were also examined. The uptake of probes $\mathrm{A}$ and $\mathrm{B}(12.0 \mu \mathrm{M})$ by INS-1E cells yielded apparent intracellular concentrations approximately one order of magnitude higher than the extracellular concentration. The two probes differed from one another by the absolute values for their respective uptake and time course, but not so by the pattern of their concentration dependency. Comparable results were recorded in HEK cells, rat isolated pancreatic islets and hepatocytes. Vastly different findings were recorded, however, in rat exocrine pancreatic cells, which do not express GLUT2. Moreover, an unusual concentration dependency for the uptake of each probe was observed in tumoral BRIN-BD11 cells. It is proposed that suitable fluorescent desnitroso-streptozotocin analogs may be used to label GLUT2-expressing cells.
\end{abstract}

Correspondence to: Professor Willy J. Malaisse, Laboratory of Experimental Hormonology, Université Libre de Bruxelles, 808 Route de Lennik, B-1070 Brussels, Belgium

E-mail: malaisse@ulb.ac.be

Key words: fluorescent desnitroso-streptozotocin analogs, labeling and imaging of GLUT2-expressing cells, immunocytochemistry of GLUT2 in INS-1E cells, rat hepatocytes, pancreatic acinar and islet cells, HEK and BRIN-BD11 cells

\section{Introduction}

The non-invasive imaging of GLUT2-expressing cells, such as insulin-producing pancreatic islet cells, remains a challenge (1). INS-1E cells are currently used as a model of glucose-responsive insulin-producing cells $(2,3)$. The aims of the present study were to document the presence of GLUT2 in INS-1E cells by immunocytochemistry and to explore its possible role in the concentration- and time-dependent uptake of two novel fluorescent desnitroso-streptozotocin analogs. For the purpose of comparison, similar experiments were conducted in human embryonic kidney (HEK) cells, rat isolated pancreatic islets, rat hepatic cells, rat exocrine pancreatic cells and BRIN-BD11 cells. In the INS-1E cells and other GLUT2-expressing cells, the cell fluorescence eventually reached a level suggesting that the intracellular concentration of the desnitroso-streptozotocin analogs exceeded, by approximately one order of magnitude, the extracellular concentration. It is proposed, therefore, that these fluorescent analogs may be used to label GLUT2-expressing cells.

\section{Materials and methods}

Fluorescent desnitroso-streptozotocin analogs. The first probe used in the present study (probe A) was prepared according to the methods of Ran et al (4), as follows. Trifluoroacetic acid (TFA; $100 \mu \mathrm{l}$ ) was added to a solution of 1,3,4,6-tetra- $O$-acetyl-2-[3-(4-tert-butoxycarbonylaminobutyl)-ureido]-2-deoxy-glucopyranose (Compound 1 in Fig. 1; $4.4 \mathrm{mg}, 8.0 \mathrm{mmol})$ in dichloromethane $(100 \mu \mathrm{l})$ and the resultant mixture was stirred at room temperature for $2 \mathrm{~h}$. After evaporation of the solvent and TFA, an oily residue was obtained. Cy5.5-NHS (1.0 mg), water (100 $\mu \mathrm{l})$, acetonitrile $(100 \mu \mathrm{l})$ and triethylamine $(10.0 \mathrm{mg})$ were added to this residue. The resulting mixture was stirred at room temperature for $4 \mathrm{~h}$, and this was followed by the addition of sodium methoxide $(108.0 \mathrm{mg})$ in methanol $(100 \mu \mathrm{l})$. The resultant mixture was stirred at room temperature overnight and the solvent was removed under vacuum to give an oily residue. This residue was subjected to a reversed-phase flash 
C18 column to obtain probe A (Cy5.5; $0.6 \mathrm{mg}$; 55\%); ESI-MS: $\mathrm{m} / \mathrm{z} 1192.9$.

The second probe used in the present study (probe B) was prepared by an adaptation of the method proposed by Ran et al (4) and based on the ATTO TEC procedure sheet whereby the dye to sugar ratio was optimized from 9:1 (dye:sugar) to a ratio of $4: 1$. TFA $(500 \mu \mathrm{l})$ was added to a solution of 1,3,4,6-tetra- $O$-acetyl-2-[3-(4-tert-butoxycarbonylamino-butyl)-ureido]-2-deoxy-glucopyranose (Compound 1 in Fig. 1; $29.8 \mathrm{mg}, 52.1 \mathrm{mmol})$ in dichloromethane $(500 \mu \mathrm{l})$, and the resultant mixture was stirred at room temperature for $2 \mathrm{~h}$. After evaporation of the solvent and TFA, an oily residue was obtained. ATTO 647N-NHS $(5.0 \mathrm{mg}, 5.9 \mu \mathrm{mol})$ was dissolved in $1.5 \mathrm{ml}$ DMSO, and triethylamine $(80 \mu \mathrm{l})$ was added to the residue. The resulting mixture was stirred at room temperature for $2 \mathrm{~h}$ and the solvent was evaporated. The residue was taken up in water and the organic phase was extracted twice with dichloromethane. The separated and combined organic layers were dried by evaporation under a vacuum. Purification was performed using Biogel chromatography in $\mathrm{MeOH}$ to give $4.4 \mathrm{mg}(83 \%)$ of a blue solid. Subsequent deacetylation was performed in $2 \mathrm{ml} \mathrm{MeOH}$ and by addition of $\mathrm{NH}_{3}$ in $\mathrm{MeOH}$ $(100 \mu \mathrm{l} ; 7 \mathrm{~N})$ and the mixture was stirred for $12 \mathrm{~h}$. MALDI-TOF MS yielded a $902.9[\mathrm{M}+\mathrm{Na}]^{+}$molecular mass (MALDI-TOF MS was by a Bruker Biflex III, using 2,5-dihydroxybenzoic acid as a matrix).

INS-1E, HEK, BRIN-BDI1, hepatic and pancreatic exocrine cells and isolated pancreatic islets. The insulin-producing INS-1E cells were kindly provided by Professor C. Wollheim (University Medical Center, Geneva, Switzerland) and cultured at $37^{\circ} \mathrm{C}$ in RPMI-1640 medium (Invitrogen Life Technologies Europe BV, Gent, Belgium) containing $11.1 \mathrm{mM}$ D-glucose and $2.0 \mathrm{mM}$ L-glutamine, and supplemented with $5 \%(\mathrm{v} / \mathrm{v})$ heat-inactivated fetal bovine serum, $1 \%(\mathrm{v} / \mathrm{v})$ penicillin (100 U/ml)-streptomycin $(100 \mu \mathrm{g} / \mathrm{ml}), 10.0 \mathrm{mM}$ HEPES, $1.0 \mathrm{mM}$ sodium pyruvate and $50.0 \mu \mathrm{M}$ 2-mercaptoethanol, in humidified air containing $5 \% \mathrm{CO}_{2}$. The INS-1E cells were used between passages 20 and 40 .

HEK-293 cells were provided by American Type Culture Collection (ATCC, Manassas, VA, USA). The HEK cells were incubated in the ATCC formulated Eagle's minimum essential medium, to which fetal bovine serum (final concentration 10\%), penicillin $(50 \mathrm{IU} / \mathrm{ml})$ and streptomycin $(50 \mu \mathrm{g} / \mathrm{ml})$ were added.

Rat pancreatic islets were isolated by the collagenase procedure (5), whilst rat pancreatic exocrine cells were isolated according to the procedure proposed by Amsterdam and Jamieson (6). The islets and exocrine cells were incubated in RPMI-1640 culture medium (Invitrogen Life Technologies). The study was approved by the Ethic Committee of Brussels Free university (Brussels, Belgium).

Rat hepatic cells were prepared according to the method of Berry and Friend (7) and incubated in DMEM medium (Gibco-BRL, Invitrogen Life Technologies) containing $10.0 \mathrm{mM}$ D-glucose, L-glutamine, penicillin, streptomycin and $10 \%$ inactivated fetal bovine serum.

BRIN-BD11 cells were kindly provided by Professor A. Herchuelz (Laboratory of Pharmacology, Brussels Free University, Brussels, Belgium) and cultured as described elsewhere (8).

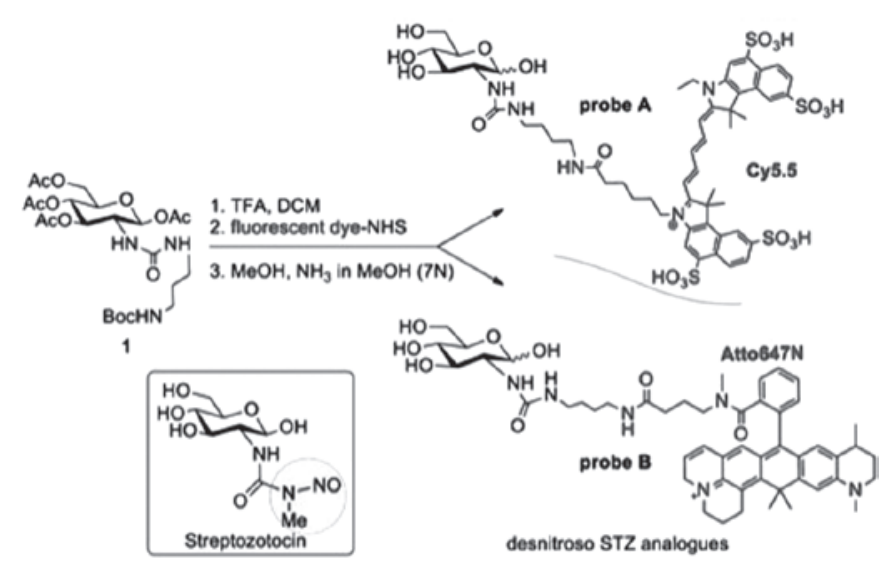

Figure 1. Fluorescent-tagged desnitroso-streptozotocin analogs.

Immunohistochemistry. INS-1E cells were plated on $13 \mathrm{~mm}$ glass coverslips, placed into 12-well plates and left to adhere and proliferate for 4 days in RPMI GlutaMAX ${ }^{\mathrm{TM}}$ medium (Gibco-BRL, Invitrogen) supplemented with $1 \mathrm{mM}$ sodium pyruvate (Gibco-BRL), penicillin-streptomycin $(100 \mathrm{U} / \mathrm{ml}$ and $100 \mu \mathrm{g} / \mathrm{ml}$, Gibco-BRL), $50 \mu \mathrm{M} \beta$-mercaptoethanol and $10 \%$ FBS. Prior to staining, cells were washed with PBS, then fixed in 4\% PAF (v/v) for $15 \mathrm{~min}$ and washed several times with TBS and TBS-Triton $0.3 \%$ (v/v). Coverslips were covered with $10 \%$ normal goat serum for $1 \mathrm{~h}$ at room temperature, followed by incubation with rabbit anti-GLUT2 antibody (Santa Cruz Biotechnology, Inc., Santa Cruz, CA, USA; sc-9117; dilution 1:100), overnight at $4^{\circ} \mathrm{C}$. The secondary antibody was a goat anti-rabbit conjugated to Alexa594 (Invitrogen; dilution 1:100). The nuclei were counterstained with DAPI. Coverslips were examined using the Axioplan microscope (Carl Zeiss, Göttingen, Germany) connected to a video camera and a complementary acquisition system.

Uptake of fluorescent desnitroso-streptozotocin analogs. In order to assess the uptake of probes A and B, groups of $\sim 70 \times 10^{3}$ cells or 15 rat isolated pancreatic islets were incubated for $15 \mathrm{~min}$ or more, up to $24 \mathrm{~h}$, in $0.1 \mathrm{ml}$ of incubation medium. After incubation, the extracellular medium was removed and after two washes, the fluorescence of the cells (or islets) was measured using a Glomax Multi Detection instrument (Promega, Leiden, The Netherlands). The results of these measurements were expressed in arbitrary units.

The reference fluorescence values measured at increasing concentrations $(0.15,0.3,0.6$ and $1.2 \mu \mathrm{M})$ of probe A or B, and expressed in arbitrary units, yielded a positive correlation $(\mathrm{P}<0.03$ or less) with the latter concentrations. In two experiments conducted in the $0.15-1.2$ or $0.3-2.0 \mu \mathrm{M}$ range, the $\mathrm{A} / \mathrm{B}$ ratios found at increasing concentrations averaged $55.1 \pm 6.6 \%(\mathrm{n}=8)$. At increasing concentrations of each probe, the fluorescent measurements were not strictly proportional to the concentration of the probe (Fig. 2). For instance, the measurements recorded at the lowest concentration of the probes represented $25.2 \pm 4.5 \%(n=4)$ of the corresponding value found within the same experiment and with the same probe at a 6-7 times higher concentration, distinct $(\mathrm{P}<0.05)$ from the theoretical value of $13.8 \pm 0.7 \% \quad(n=4)$ based on the assumption of a rule of proportionality. 


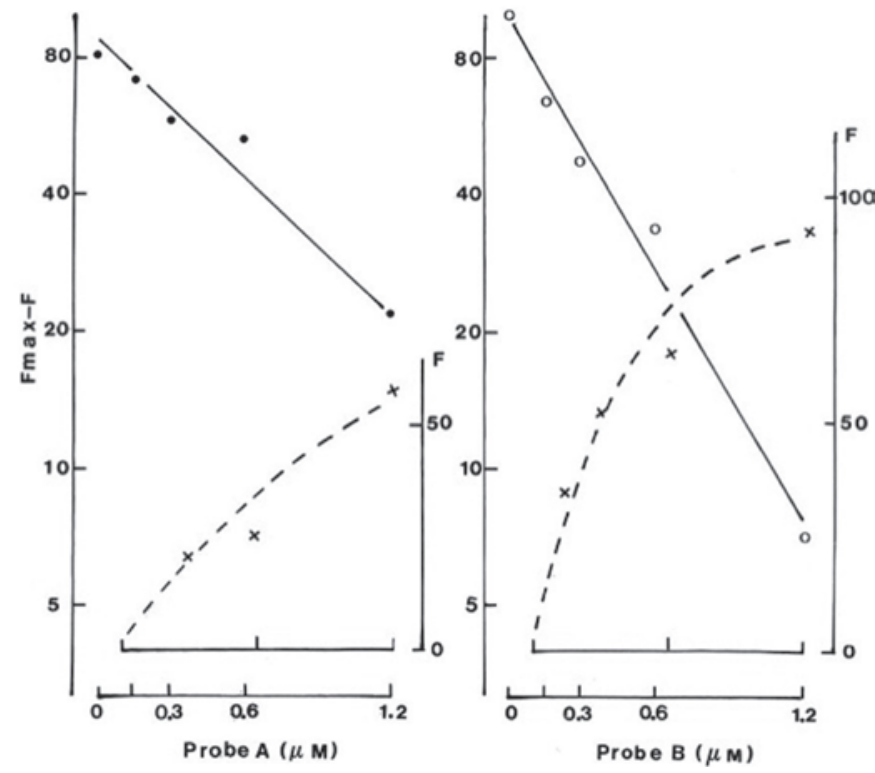

Figure 2. Fluorescence of probe standards in a representative experiment. The fluorescence $(\mathrm{F})$ of probe A (left) and probe B (right) at increasing probe concentrations (0.15-0.3-0.6-1.2 $\mu \mathrm{M})$ is illustrated in the inset graph (crosses and dashed line). The differences between the estimated maximal fluorescence $\left(\mathrm{F}_{\max }\right)$ and $\mathrm{F}$, on a logarithmic scale, are illustrated in the main panels (circles and solid line), the oblique solid line corresponding to the regression line.

Fluorescence imaging. Cells (or isolated pancreatic islets) were seeded on 96-well cell culture plates (Greiner Bio-One, Alphen aan den Rijn, The Netherlands). After incubation, the probe-containing medium was removed and the plates were washed twice.

The fluorescence imaging of labeled cells was achieved using an Axiovert 200m microscope (Carl Zeiss NV-SA) and a TexaRed filter.

D-glucose phosphorylation in INS-1E cell homogenates. Groups of $2 \times 10^{6}$ INS-1E cells were sonicated three times for $10 \mathrm{sec}$ in $1.0 \mathrm{ml}$ of an iced Hepes- $\mathrm{NaOH}$ buffer $(75.0 \mathrm{mM}$, $\mathrm{pH}$ 7.4) containing $150.0 \mathrm{mM} \mathrm{KCl}, 15.0 \mathrm{mM} \mathrm{K \textrm {K } _ { 2 }} \mathrm{PO}_{4}$, $16.5 \mathrm{mM} \mathrm{MgCl}_{2}$ and $1.5 \mathrm{mM}$ EDTA. Aliquots $(50 \mu \mathrm{l})$ of this homogenate were mixed with $10 \mu \mathrm{l}$ of the same homogenization buffer and $60 \mu \mathrm{l}$ of the same Hepes-NaOH buffer as mentioned above, but diluted with $\mathrm{H}_{2} \mathrm{O}$ in a 2/1 ratio (yielding a $50.0 \mathrm{mM}$ Hepes- $\mathrm{NaOH}$ buffer) and enriched with ATP (20.0 mM), D-glucose (7.0 or $50.0 \mathrm{mM})$ and a trace amount of D- $\left[\mathrm{U}-{ }^{14} \mathrm{C}\right]$ glucose. After $60 \mathrm{~min}$ incubation at $37^{\circ} \mathrm{C}, 1.0 \mathrm{ml}$ of cold $\mathrm{H}_{2} \mathrm{O}$ was added to each sample and the radioactive acidic metabolites were separated by anion-exchange chromatography (9).

Ethical approval. The study was approved by the Ethic Committee of Brussels Free university (Brussels, Belgium).

Statistical analysis. All results are expressed as the mean values $( \pm$ SEM) together with either the number of individual determinations (n) or degree of freedom (df). The statistical significance of differences between mean values was assessed by use of Student's t-test.

\section{Results}

Immunocytochemistry of GLUT2. As illustrated in Fig. 3, GLUT2 protein was largely detected by immunofluorescence in the membrane of INS-1E cells, but also in the cytosol of these cells.

Uptake of desnitroso-streptozotocin analogs. In a representative experiment, the fluorescence of INS-1E cells not exposed to any probe did not exceed 5.1 arbitrary units $/ 10^{3}$. In the same experiment, after $24 \mathrm{~h}$ incubation at the highest probe concentration $(12.0 \mu \mathrm{M})$ used in the present study, the fluorescence of INS-1E cells with probe A and B averaged, respectively, 50.4 and 247.2 arbitrary units $/ 10^{3}$. Taking into account both the reference values for the fluorescence of the probes themselves (see Materials and methods) and the volume of INS-1E cells, i.e. $1.5 \mathrm{nl} / 10^{3}(10)$, the latter value would yield apparent intracellular concentrations of $\sim 78.4 \mu \mathrm{M}$ with probe $\mathrm{A}$ and $217.3 \mu \mathrm{M}$ with probe $\mathrm{B}$ : approximately one order of magnitude higher than the initial extracellular concentration $(12.0 \mu \mathrm{M})$.

In a series of six experiments conducted in INS-1E cells incubated for 5 or $24 \mathrm{~h}$ in the presence of probe A or B in concentration ranges of $0.25-0.5-1.0 \mu \mathrm{M}$ or $3.0-6.0-12.0 \mu \mathrm{M}$, the probe $\mathrm{A} /$ probe $\mathrm{B}$ ratio for the fluorescence of the cells averaged $21.8 \pm 1.8 \%(n=18)$. The data collected in cells exposed to probe $\mathrm{A}$ or $\mathrm{B}$ in the low concentration range of $0.25-0.5-1.0 \mu \mathrm{M}$ yielded an $A / B$ ratio of cell fluorescence $(21.9 \pm 2.5 \% ; n=6)$ virtually identical to that recorded in the higher concentration range of 3.0-6.0-12.0 $\mu \mathrm{M}(21.7 \pm 2.5 \%$; $=12)$. Such ratios were markedly lower $(\mathrm{P}<0.005$ or less) than those observed for the fluorescence of the probes themselves $(55.1 \pm 6.6 \% ; n=8)$, indicating that, under identical experimental conditions, the net uptake of probe A by the INS-1E cells, considered in molar units, only represented $\sim 40 \%$ of that of probe B.

The A/B ratio for INS-1E cell fluorescence was not identical, however, after either 5 or $24 \mathrm{~h}$ incubation. Thus, the value recorded after $5 \mathrm{~h}$ incubation averaged $134.1 \pm 11.7 \%$ $(n=9 ; \mathrm{P}<0.02)$ of the paired value recorded within the same experiment(s) and at the same concentration of each probe after $24 \mathrm{~h}$ incubation. This finding suggests that a difference may prevail between the two probes in terms of the time course for their uptake by the INS-1E cells.

In agreement with the latter suggestion, the time course for the uptake of probe A or B indicated that, after $5 \mathrm{~h}$ incubation, the fluorescence of INS-1E cells exposed to these probes in the 3.0-6.0-12.0 $\mu \mathrm{M}$ range amounted to $89.7 \pm 2.9 \%(\mathrm{n}=6)$ in the case of probe A and $61.6 \pm 3.5 \%(n=6)$ in the case of probe $B$ of the paired value recorded within the same experiment(s) with the same probe and at the same probe concentration after $24 \mathrm{~h}$ incubation. In addition to differing significantly $(\mathrm{P}<0.001)$ from one another, the latter two mean percentages were both significantly lower than unity $(\mathrm{P}<0.02$ or less $)$ and both significantly higher $(\mathrm{P}<0.001)$ than the theoretical value of $20.8 \%$ based on the assumption of a rule of proportionality between uptake of the probe and length of incubation.

The concentration dependency for the uptake of probes A and $\mathrm{B}$ was examined in 3 experiments conducted in the $0.25-0.5-1.0 \mu \mathrm{M}$ range and in 4 experiments conducted in the 3.0-6.0-12.0 $\mu \mathrm{M}$ range. The results of the latter experiments are shown in Fig. 4. The results indicate that, after 5 or $24 \mathrm{~h}$ 

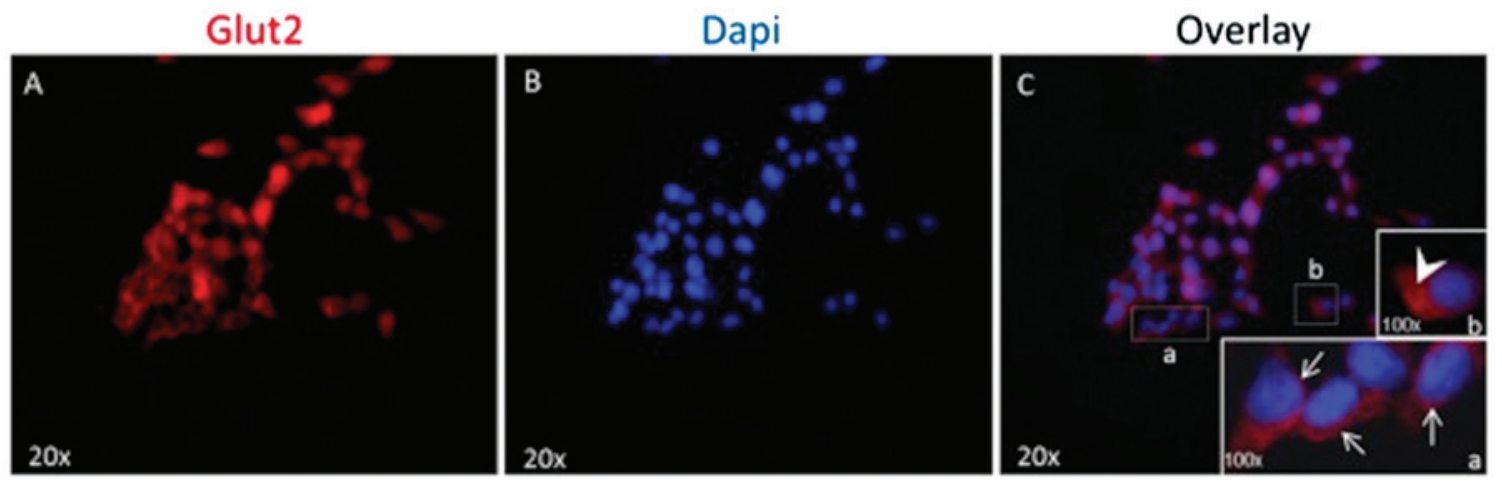

Figure 3. INS-1E cells were stained for the glucose transporter GLUT2 (A, red) and nuclei were counterstained with DAPI (B, blue). GLUT2 protein was largely detected by immunofluorescence in the membrane of INS-1E cells (C-a, arrow) but also in the cytosol (C-b, arrowhead). Images A, B and C were captured at x20 magnification. Details in the insets were obtained using the magnification tool of Adobe Photoshop 7.0 and correspond to x100 magnification.

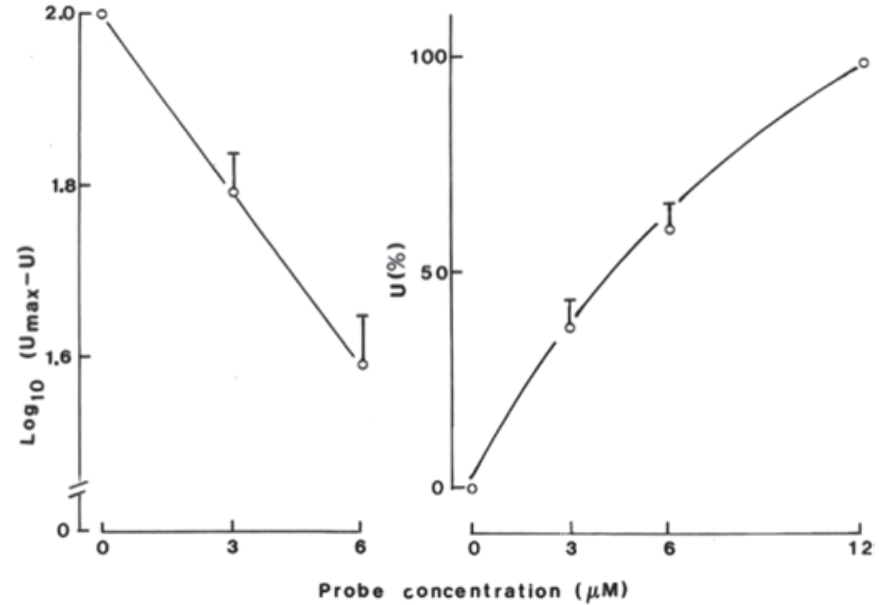

Figure 4. Right panel: correlation between the uptake of probes A and B (U), as judged from the fluorescence of INS-1E cells incubated for either 5 or $24 \mathrm{~h}$, and the probe concentration. Mean values $( \pm$ SEM) refer to 8 individual measurements, and are expressed relative to the paired value found for the same probe after the same time of incubation in the presence of a $12.0 \mu \mathrm{M}$ concentration (100\%). Left panel: semi-logarithmic presentation of the relationship between $\mathrm{U}_{\max }-\mathrm{U}$ and probe concentration; the experimental data are the same as in the right panel, the close-to-maximal value $\left(\mathrm{U}_{\max }\right)$ being taken as that recorded at a $12.0 \mu \mathrm{M}$ probe concentration (100\%). The oblique line corresponds to the regression line.

incubation in the presence of either probe $\mathrm{A}$ or probe $\mathrm{B}$, the fluorescence of the INS-1E cells averaged 3.0 and $6.0 \mu \mathrm{M}$, respectively, which was $37.5 \pm 6.7$ and $60.7 \pm 5.4 \%(\mathrm{n}=8)$ of the corresponding value recorded at $12.0 \mu \mathrm{M}$, yielding a curvilinear pattern with downward concavity (Fig. 3, right panel). When the cell fluorescence observed at 3.0 and $6.0 \mu \mathrm{M}$ was expressed relative to the close-to-maximal value $\left(\mathrm{U}_{\max }\right)$ recorded at $12.0 \mu \mathrm{M}$, the results were compatible with an exponential pattern responding to the equation $\mathrm{U}=\mathrm{U}_{\max }$ $\left(1-\mathrm{e}^{-\mathrm{KC}}\right)$, in which $\mathrm{U}$ represents the uptake of the probe at a concentration $(\mathrm{C})$ and $\mathrm{K}$ the slope of the corresponding regression line established in semi-logarithmic coordinates. Thus, as shown in Fig. 4 (left panel), the regression line between the decimal logarithmic values of $\left(U_{\max }-U\right)$ and the concentration of the probe yielded a correlation coefficient equal to unity and a negative slope of $-0.0676 \mu \mathrm{M}^{-1}$. At lower probe concentrations in the 0.25-0.5-1.0 $\mu \mathrm{M}$ range, the measurements of INS-1E cell fluorescence also yielded a curve with downward concavity, and the results recorded at 0.25 and $0.5 \mu \mathrm{M}$ averaged $35.1 \pm 8.7 \%(\mathrm{n}=4)$ and $71.3 \pm 8.1 \%$ $(n=4)$, respectively, of the paired corresponding value observed under the same experimental conditions (30 min, $5 \mathrm{~h}$ and $24 \mathrm{~h}$ incubation) at the $1.0 \mu \mathrm{M}$ concentration of the same probe. These percentages did not differ significantly from those expected from the regression line drawn in the left panel of Fig. 4.

When compared within the same experiment(s) and after 5 or $24 \mathrm{~h}$ incubation, there was little difference in the fluorescence of INS-1E cells exposed to either probe A or probe B (3.0, 6.0 and $12.0 \mu \mathrm{M})$ and incubated at either low $(2.8 \mathrm{mM})$ or high $(16.7 \mathrm{mM})$ concentrations of D-glucose, with a paired $2.8 \mathrm{mM} / 16.7 \mathrm{mM}$ ratio averaging $109.3 \pm 16.4 \%$ ( $\mathrm{n}=12 ; \mathrm{P}>0.59$ vs. unity). Thus, there was no evidence that the uptake of either probe $\mathrm{A}$ or probe $\mathrm{B}$ was affected by the concentration of D-glucose in the incubation medium.

The uptake of probes A and/or B by INS-1E cells was also compared to that found, under comparable experimental conditions, in HEK-293 cells, taken as representative of GLUT2-expressing kidney cells (11), rat pancreatic islets, rat hepatocytes, rat exocrine pancreatic cells and BRIN-BD11 cells.

The fluorescence measurements observed in the HEK-293 cells yielded information closely comparable to that collected in the INS-1E cells. Firstly, whether in HEK cells exposed for either 5 or $24 \mathrm{~h}$ to either probe A or probe B, their respective uptake at $12.0 \mu \mathrm{M}$ was $2.85 \pm 0.34$ times higher $(\mathrm{n}=4$; $\mathrm{P}<0.02)$ than the paired value observed at a $3.0 \mu \mathrm{M}$ concentration, indicating a lack of proportionality $(\mathrm{P}<0.05)$ between uptake and concentration. Furthermore, the 3.0/12.0 $\mu \mathrm{M}$ ratio for the fluorescence of HEK cells averaged $36.8 \pm 4.8 \%(n=4)$, a value almost identical $(\mathrm{P}>0.94)$ to that computed in the INS-1E cells ( $37.5 \pm 6.7 \% ; n=8)$. Secondly, the paired probe A/ probe $B$ ratio for the fluorescence of HEK cells averaged $23.3 \pm 2.6 \%(n=4)$, a value again almost identical $(P>0.71)$ to that found in INS-1E cells $(21.8 \pm 1.8 \% ; \mathrm{n}=18)$. Lastly, the fluorescence of HEK cells exposed for $5 \mathrm{~h}$ to probes A or B $(3.0$ or $12.0 \mu \mathrm{M})$ represented $50.7 \pm 5.0 \%(\mathrm{n}=4)$ of the paired value recorded after $24 \mathrm{~h}$ of incubation, such a percentage being significantly higher $(\mathrm{P}<0.01)$ than the theoretical value of $20.8 \%$ based on the assumption of a rule of proportion- 
ality between probe uptake and length of incubation, as also observed in INS-1E cells.

In rat isolated pancreatic islets exposed to probe $\mathrm{A}$ or $\mathrm{B}$ (3.0, 6.0 and $12.0 \mu \mathrm{M})$, the fluorescence measurements recorded after only $15 \mathrm{~min}$ incubation indicated that the net uptake of these probes had already reached its close-toequilibrium value. Thus, the values observed after only $15 \mathrm{~min}$ incubation averaged $106.4 \pm 1.4 \%(n=6)$ of the corresponding measurements made after $24 \mathrm{~h}$ incubation. As judged from the comparison of measurements made in the islets at increasing concentrations of each probe $(3.0,6.0$ and $12.0 \mu \mathrm{M})$, the concentration-uptake relationship differed with probe $\mathrm{A}$, as compared to probe B. In the case of probe A, the uptake was grossly proportional to the concentration. For instance, whether after $15 \mathrm{~min}$ or $24 \mathrm{~h}$ incubation, it represented $22.3 \pm 1.8 \%$ and $50.6 \pm 1.1 \%$, at 3.0 and $6.0 \mu \mathrm{M}$, respectively, of the corresponding value found at $12.0 \mu \mathrm{M}$. In the case of probe $\mathrm{B}$, the measurements at $3.0 \mu \mathrm{M}$ averaged $73.2 \pm 2.1 \%$ of those recorded at $6.0 \mu \mathrm{M}$, the latter measurement representing $70.9 \pm 0.2 \%$ of that found at $12.0 \mu \mathrm{M}$. The results obtained in the islets with probe B are thus similar to those illustrated in Fig. 4, with a negative coefficient of correlation between $\log _{10}$ $\left(\mathrm{U}_{\max }-\mathrm{U}\right)$ and concentration $(0,3.0$ and $6.0 \mu \mathrm{M})$ amounting to -0.9943 and the slope of the corresponding regression line yielding a negative value of $-0.0894 \mu \mathrm{M}^{-1}$. As expected from these findings, the probe A/probe B paired ratio for islet fluorescence, as computed after either $15 \mathrm{~min}$ or $24 \mathrm{~h}$ incubation, increased from $38.0 \pm 1.4 \%$ at $3.0 \mu \mathrm{M}$ to $63.0 \pm 0.2 \%$ at $6.0 \mu \mathrm{M}$ and $88.3 \pm 2.0 \%$ at $12.0 \mu \mathrm{M}$.

After $30 \mathrm{~min}$ incubation in the presence of probe B tested in the $0.25-0.5-1.0 \mu \mathrm{M}$ range, the concentration-dependent fluorescence of rat hepatic cells and INS-1E cells, assessed within the same experiment, yielded a comparable relationship. Thus, according to the analytical procedure illustrated in Fig. 3, the slope of the regression line ( \pm sample standard deviation of the regression coefficient) was almost identical $(\mathrm{P}>0.87)$ in hepatocytes $\left(0.093 \pm 0.010 \mu \mathrm{M}^{-1}\right)$ and INS-1E cells $\left(0.091 \pm 0.009 \mu \mathrm{M}^{-1}\right)$ with a correlation coefficient between $\log _{10}\left(\mathrm{U}_{\max }-\mathrm{U}\right)$ and $\mathrm{C}$ amounting, respectively, to 0.9912 in hepatocytes $(\mathrm{n}=4 ; \mathrm{P}<0.009)$ and 0.9850 in INS-1E cells $(\mathrm{n}=4$; $\mathrm{P}<0.02$ ). The absolute value for fluorescence, however, was 4-5 times higher in hepatic cells than in INS-1E cells.

Within the same experiment, the results collected in rat exocrine pancreatic cells, which do not express GLUT2 and were incubated under the same experimental conditions, differed from those found in either hepatic cells or INS-1E cells in several respects. Firstly, the dispersion of individual measurements at increasing concentrations of probe B was greater in rat exocrine pancreatic cells than in either rat liver cells or INS-1E cells, as documented by the lower correlation coefficient between cell fluorescence and probe concentration in the exocrine cells $(r=0.8686 ; n=6$; $\mathrm{P}<0.03)$ than in the liver cells $(\mathrm{r}=0.8969 ; \mathrm{n}=6 ; \mathrm{P}<0.001)$ or INS-1E cells $(r=0.9757 ; n=6 ; P<0.001)$, and by the much higher magnitude of the standard deviation of the regression coefficient between cell fluorescence and probe concentration, expressed relative to the latter coefficient, in exocrine cells $(57.1 \%)$ than in either liver cells $(16.4 \%)$ or INS-1E cells $(22.5 \%)$. Secondly, at any given probe concentration, the fluorescence of exocrine cells was markedly lower than that

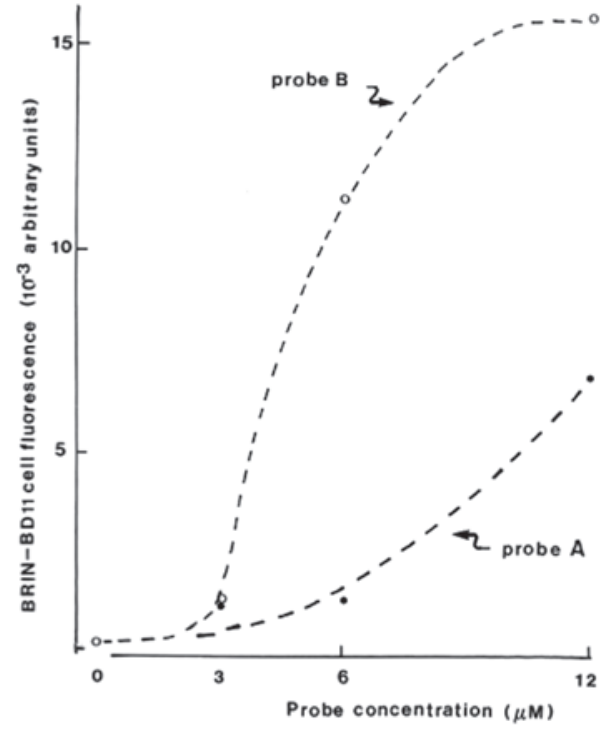

Figure 5. BRIN-BD11 cell fluorescence after $24 \mathrm{~h}$ incubation in the presence of increasing concentrations of either probe A (closed circles and dashed line) or probe B (open circles and dotted line).

of liver cells or INS-1E cells. Expressed in arbitrary units, the slope of the regression line between cell fluorescence and probe concentration did not exceed $1.86 \pm 1.0610^{3} / \mu \mathrm{M}$, a value $\sim 15$ times lower than that found for hepatic cells, $28.28 \pm 4.63$ $10^{3} / \mu \mathrm{M}$. The slope found in the exocrine cells was also 2-3 times lower than that found in the INS-1E cells $(4.25 \pm 0.95$ $\left.10^{3} / \mu \mathrm{M}\right)$, within the same experiment. The statistical significance of the difference was confirmed by covariance analysis $(\mathrm{F}=11.3, \mathrm{f}=1,8 ; \mathrm{P}=0.01)$.

The possible role of distinct glucose transporters in the uptake of the two probes examined in this study was supported by findings collected in BRIN-BD11 cells established by electrofusion of RINm5F cells with New England Deaconess Hospital (NEDH) rat pancreatic islet cells (12). The metabolism of D-glucose in the BRIN-BD11 cells displays several analogies with that of the hexose in the parent RINm5F cells (13). For instance, the concentration dependency of D-[5- $\left.{ }^{3} \mathrm{H}\right]$ glucose utilization is almost identical in RINm5F and BRIN-BD11 cells. The total energy yield from D-glucose catabolism is also similar in these two cell lines (13). The RINm5F cells have lost an essential attribute of the glucose sensor device in normal insulin-producing cells, namely the capacity to ensure the equilibrium of D-glucose concentrations across the plasma membrane (14), coinciding with a severely impaired uptake of the diabetogenic agent alloxan and with resulting resistance to its cytotoxic action (15). A comparable situation may prevail in BRIN-BD11 cells. In turn, such a situation may account for the unusual concentration dependency for the uptake of probes $A$ and B by BRIN-BD11 cells with either an upward concavity (probe A) or sigmoidal pattern (probe B), as shown in Fig. 5. In these experiments, the increase in the fluorescence of the BRIN-BD11 cells in the low range of probe concentrations, expressed relative to the increment in probe concentrations, represented no more than $16.2 \pm 4.8 \%(n=3)$ of that recorded with the same probe in the steepest segments of the curves shown in Fig. 5. Moreover, whilst the probe A/probe B ratio in cell fluorescence amounted to $85.8 \%$ at the lowest probe 

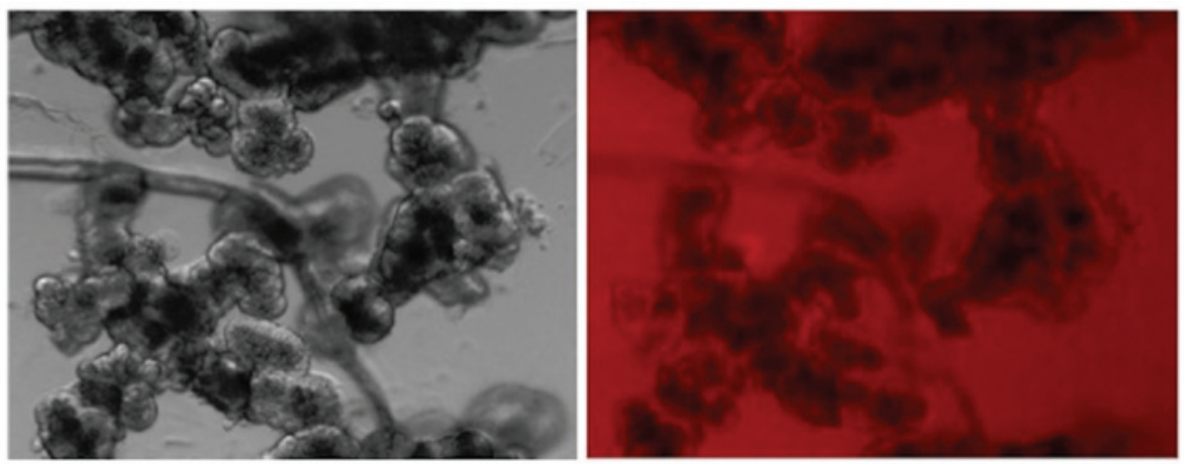

Figure 6. Fluorescence imaging of rat pancreatic exocrine cells incubated for $30 \mathrm{~min}$ with probe $\mathrm{B}(1.0 \mu \mathrm{M})$.
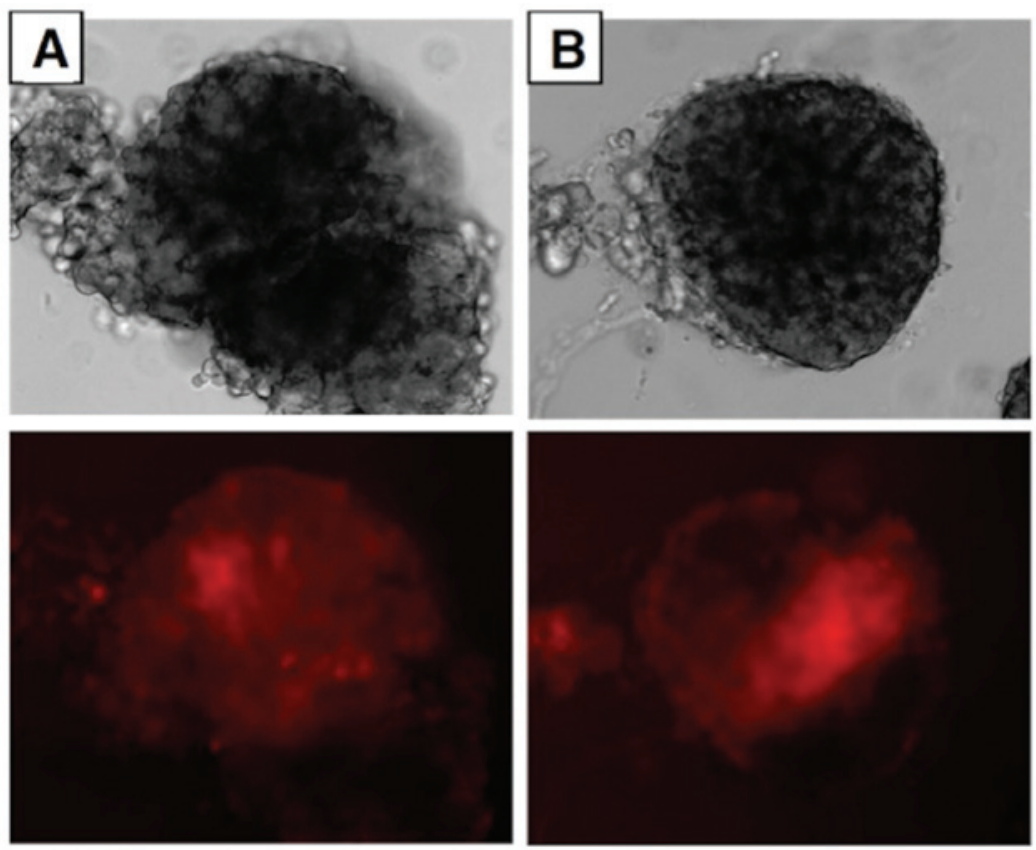

Figure 7. Fluorescence imaging of rat pancreatic islets incubated for 30 min with probe B at (A) $3.0 \mu \mathrm{M}$ or (B) $6.0 \mu \mathrm{M}$.
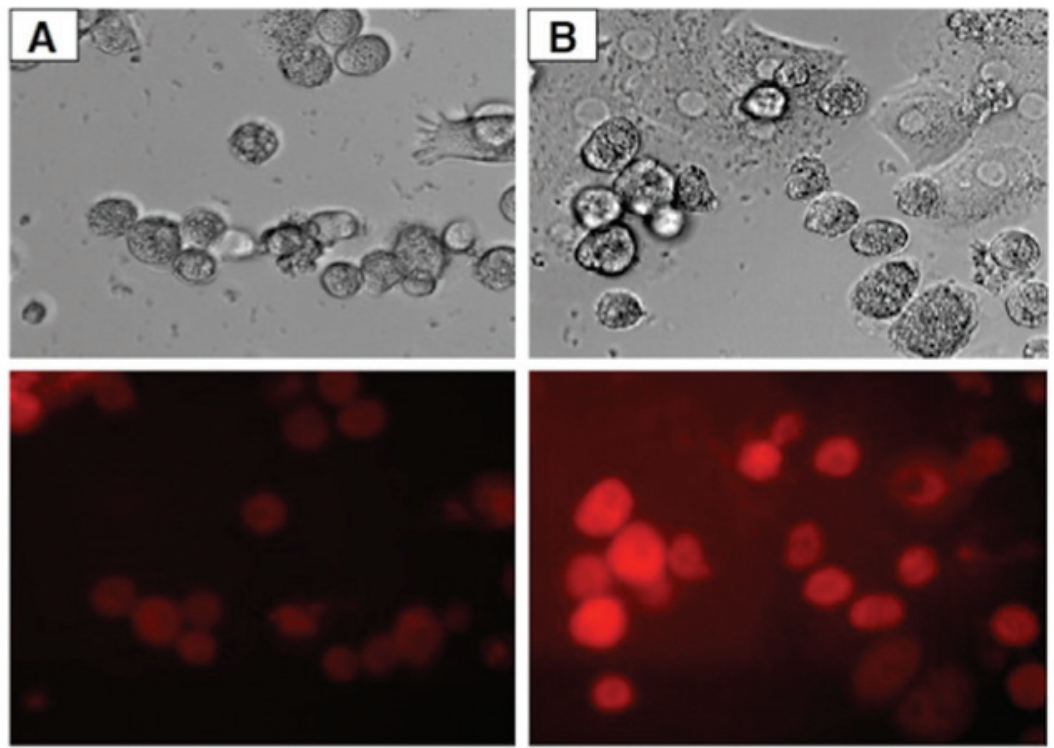

Figure 8. Fluorescence imaging of rat hepatocytes incubated for $30 \mathrm{~min}$ with probe B at (A) $0.5 \mu \mathrm{M}$ and (B) $1.0 \mu \mathrm{M}$. 
concentration $(3.6 \mu \mathrm{M})$, it reached a value two times lower $(42.5 \%)$ at the highest probe concentration $(12.0 \mu \mathrm{M})$.

At the lowest extracellular probe concentration used in these experiments $(3.0 \mu \mathrm{M})$, their estimated intracellular concentration, taking into account a BRIN-BD11 cell volume of $1.60 \mathrm{nl} / 10^{3}$ cells (8), was close to 16.5 and $10.9 \mu \mathrm{M}$ for probe $\mathrm{A}$ and $\mathrm{B}$, respectively, as compared to corresponding values of 20.6 and $76.0 \mu \mathrm{M}$ in INS-1E cells. The marked difference observed under these experimental conditions in terms of the apparent uptake of probe B by BRIN-BD11 cells versus INS-1E cells was reduced at the highest probe concentration $(12.0 \mu \mathrm{M})$ with estimated intracellular concentrations of $135.6 \mu \mathrm{M}$ (probe A) and $180.3 \mu \mathrm{M}$ (probe B) in BRINBD11 cells, as compared to $78.4 \mu \mathrm{M}$ (probe $\mathrm{A}$ ) and $217.3 \mu \mathrm{M}$ (probe B) in INS-1E cells.

Fluorescent imaging. Even at a $1.0 \mu \mathrm{M}$ concentration of probe $B$, uptake could not be documented by fluorescence imaging in rat exocrine pancreatic cells (Fig. 6), in contrast with the findings made in rat pancreatic islets (Fig. 7), rat liver cells (Fig. 8) and INS-1E cells (data not shown).

D-glucose phosphorylation. At 3.5 and $25.0 \mathrm{mM}$ D-glucose, the phosphorylation of hexose by INS-1E cell homogenates averaged, respectively, $13.8 \pm 1.1$ and $55.8 \pm 2.1 \mathrm{pmol} / 10^{3}$ cells per $60 \mathrm{~min}(\mathrm{n}=8-9)$. The latter values were not significantly different $\left(\mathrm{P}>0.34\right.$ or more) from the conversion of $\mathrm{D}-\left[5-{ }^{3} \mathrm{H}\right]$ glucose to ${ }^{3} \mathrm{HOH}$ by intact INS-1E cells incubated at either $2.8 \mathrm{mM}$ D-glucose $\left(11.1 \pm 3.2 \mathrm{pmol} / 10^{3}\right.$ cells per $\left.60 \mathrm{~min}\right)$ or $16.7 \mathrm{mM}$ D-glucose $\left(46.3 \pm 5.7 \mathrm{pmol} / 10^{3}\right.$ cells per $\left.60 \mathrm{~min}\right)$, as previously reported (16).

\section{Discussion}

The present study documents the presence of both GLUT2 and a high $\mathrm{K}_{\mathrm{m}}$ glucokinase-like catalytic activity in INS-1E cells. These attributes are well suited to account for the glucose-sensing capacity of these cells (3). The high similarity between the rate of D-glucose phosphorylation by INS-1E cell homogenates and that of $\mathrm{D}-\left[5-{ }^{3} \mathrm{H}\right]$ glucose utilization by intact cells supports the view that the concentration of D-glucose in the cytosol of INS-1E cells is close to its extracellular concentration and that the glucokinase-like enzyme represents the key determinant of D-glucose phosphorylation and further catabolism.

The labeling of insulin-producing cells remains a challenge, as recently reviewed (1). The present study dealt mainly with the use of fluorescent desnitroso-streptozotocin analogs using a more hydrophilic and a more hydrophobic dye component. It may be objected that this approach is restricted to the ex vivo labeling of insulin-producing cells. However, it should not be ruled out that the detection and quantification of pancreatic $\beta$-cells in vivo could be achieved using the present fluorescent probes and a suitable fluorescence detection instrument transiently inserted in the peritoneal cavity.

The concentration- and time-dependent fluorescence of cells exposed to either probe A or B yielded comparable results in rat isolated pancreatic islets and either INS-1E, HEK or hepatic cells, whilst a different situation prevailed in rat exocrine pancreatic cells or BRIN-BD11 cells. Moreover, a pronounced fluorescence in the cells exposed to either probe A or B was rapidly reached despite the fact that the extracellular concentration of these probes, as tested in the present study, remained in the $0.15-1.2 \mu \mathrm{M}$ range. Differences in the cell response to probe $\mathrm{A}$ and probe $\mathrm{B}$, as documented in the present study, may be accounted for by their different chemical structure and hydrophobicity.

In conclusion, the present study provides novel findings considered as potentially helpful in the labeling of GLUT2expressing cells with a fluorescent probe.

\section{Acknowledgements}

This study was supported by the European Community's Seventh Framework Programme FP7/2007-2013-FP7NMP-In Vivo Imaging of Beta-cell by Applied Nano Technology under grant agreement No. (228-993)(VIBRANT).

\section{References}

1. Malaisse WJ and Maedler K: Imaging of the $\beta$-cells of the islets of Langerhans. Diab Res Clin Pract 98: 11-18, 2012.

2. Asfari M, Janjic D, Meda P, Li G, Halban PA and Wollheim CB: Establishment of 2-mercaptoethanol-dependent differentiated insulin-secreting cell lines. Endocrinology 130: 167-178, 1992.

3. Merglen A, Theander S, Rubi B, Chaffard G, Wollheim CB and Maechler P: Glucose sensitivity and metabolism-secretion coupling studied during two-year continuous culture of INS-1E insulinoma cells. Endocrinology 145: 667-678, 2004.

4. Ran C, Pantazopoulos P, Medarova Z and Moore A: Synthesis and testing of beta-cell specific streptozotocin-derived nearinfrared imaging probes. Angew Chem Int Ed 46: 8998-9001, 2007.

5. Malaisse-Lagae F and Malaisse WJ: Insulin release by pancreatic islets. In: Methods in Diabetes Research. Vol. I, part B, Larner J and Pohl S (eds). John Wiley \& Sons, New York, pp147-152, 1984.

6. Amsterdam A and Jamieson D: Studies on dispersed pancreatic exocrine cells. II. Functional characteristics of separated cells. J Cell Biol 63: 1057-1073, 1974.

7. Berry MN and Friend DS: High-yield preparation of isolated liver parenchymal cells. J Cell Biol 43: 506-520, 1969.

8. Crutzen R, Shlyonsky V, Louchami K, Virreira M, Hupkens E, Boom A, Sener A, Malaisse WJ and Beauwens R: Does $\mathrm{NAD}(\mathrm{P}) \mathrm{H}$ oxidase-derived $\mathrm{H}_{2} \mathrm{O}_{2}$ participate in hypotonicityinduced insulin release by activating VRAC in $\beta$-cells? Eur J Physiol 463: 377-390, 2012.

9. Giroix M-H, Sener A, Pipeleers DG and Malaisse WJ : Hexose metabolism in pancreatic islets. Inhibition of hexokinase. Biochem J 223: 447-453, 1984.

10. Orecna M, Hafko R, Bacova Z, Podskocova J, Chorvat Jr D and Strbak V: Different secretory response of pancreatic islets and insulin secreting cell lines INS-1 and INS-1E to osmotic stimuli. Physiol Rev 57: 935-945, 2008.

11. Wallner EI, Wada J, Tramonti G, Lin S and Kanwar YS: Status of glucose transporters in the mammalian kidney and renal development. Ren Fail 23: 301-310, 2001.

12. McClenaghan NH, Barnett CR, Ah-Sing E, Abdel-Wahab YHA, O'Harte FPM, Yoon T-W, Swanston-Flatt SK and Flatt PR: Characterization of a novel glucose-responsive insulin-secreting cell line, BRIN-BD11, produced by electrofusion. Diabetes 45: 1132-1140, 1996.

13. Rasschaert J, Flatt PR, Barnett CR, McClenaghan NH and Malaisse WJ: D-glucose metabolism in BRIN-BD11 islet cells. Biochem Mol Med 57: 97-105, 1996

14. Sener A, Giroix M-H and Malaisse WJ: Impaired uptake of D-glucose by tumoral insulin-producing cells. Biochem Int 12: 913-919, 1986.

15. Sener A and Malaisse WJ: Resistance to alloxan of tumoral insulin-producing cells. FEBS Lett 193: 150-152, 1985.

16. Bakkali Nadi A, Olivares E and Malaisse WJ: D-glucose metabolism in normal dispersed islet cells and tumoral INS-1 cells. Mol Cell Biochem 210: 167-172, 2000. 